\title{
Kultura wysoka w polityce
}

\author{
Ilona Wilk-Suwa
}

Uniwersytet Łódzki

\begin{abstract}
Abstrakt. Przytaczanie przez polityków cudzych wywodów, powoływanie się na czyjąś twórczość to zjawisko rzadko spotykane, ale budzące skrajne emocje, dlatego też stanowi temat przewodni niniejszego tekstu. Przywołanie (zwłaszcza niedokładne) fragmentu obcego autorstwa może powodować niezrozumienie, pomyłki w odczytaniu treści i zmianę pierwotnego sensu, a dzięki dostępowi do mediów każdy ze stosowanych na scenie politycznej tego typu chwytów retorycznych można wyśledzić i kilkakrotnie obejrzeć. Politycy, podobnie jak aktorzy, poprzez dobór określonych środków autoprezentacji (w tym przypadku cytatów z literatury pięknej, powoływanie się na autora cieszącego się uznaniem ogółu) przekazują odbiorcom rzeczywistość zmienioną, taką, jaką chcieliby, żeby ci widzieli (Goffman 2008). Analizowana mowa werbalna w ławach sejmowych nacechowana jest dużym ładunkiem emocjonalnym i obrazuje, daleki od klasycznych kanonów, savoir vivre językowy (Marcjanik 2014; Achtelik, Tambor 2013). Bon ton słowne w Sejmie ma poprzez swoje zastosowanie spełniać wiele funkcji, od grzecznego sarkazmu wobec współtowarzyszy, przez manifest supremacji, do prezentacji osobistej erudycji. Na wstępie artykułu dokonano opisu najczęściej używanych w tekście pojęć. W dalszej części zajęto się szczegółowym omówieniem filmików z udziałem polityków, którzy podczas swoich publicznych wystąpień przytaczali treści z literatury pięknej. W podsumowaniu skupiono się na funkcji cytowań oraz wzięto pod uwagę pozytywne aspekty korzystania z literatury przez osoby wyłonione podczas wyborów do sprawowania funkcji publicznych.
\end{abstract}

Słowa kluczowe: polityka, politycy, literatura, emocje, kultura wysoka 


\section{Wstęp}

Słowo jest elementem mowy, a więc również języka, niezbędnym do określenia wszelkich pojęć, tak rzeczywistych, jak i nierzeczywistych, a także abstrakcyjnych oraz bliskich i dalekich naszemu pojmowaniu. Wykorzystywanie słów w odpowiedni sposób (w wypowiedzi ustnej lub pisemnej) niesie ze sobą konkretne znaczenie, a także symbolikę. Z siły drzemiącej w słowach zdawali sobie sprawę już twórcy starożytnych pieśni i poematów przekazywanych $\mathrm{w}$ formie ustnej z pokolenia na pokolenie. Miały one sławić bohaterów, idee, wydarzenia historyczne i zagrzewać do walki o słuszną sprawę. Świadomość mocy słów posiadają również politycy, dla których są one orężem walki o wyborców. Aktorzy sceny politycznej, sięgając po cytaty, wykorzystują chwyt retoryczny zwany argumentum ad verecunidam (argument odwołujący się do poważania). Polega on na wykorzystaniu passusu (często w obcym języku) „Z powołaniem się na autora cieszącego się uznaniem audytorium" (Korolko 1998: 99).

Każda wypowiedź przy odpowiednim akompaniamencie, to jest oprawie przestrzennej, technicznej, architektonicznej i wizualnej, może wyrażać coś zupełnie innego - niekiedy nawet przeciwnego niż pierwotnie zakładano. Dlatego też wielcy tego świata: politycy, przedstawiciele Kościoła, biznesmeni, podejmują decyzję o wystąpieniach w miejscach takich, jak: sale dyskusyjne, ambona czy ławy sejmowe. Słowa niosą (a przynajmniej powinny nieść) konkretne przesłanie. Wie o tym każdy, nie tylko wytrawny mistrz retoryki.

W wystąpieniach sejmowych, które stanowią przedmiot analizy w niniejszej książce, zdarzają się sporadycznie sytuacje wykorzystania przez polityka wiedzy literackiej w celu zaprezentowania, a także uargumentowania swoich racji oraz wzbudzenia zainteresowania wokół formacji politycznych, których się jest członkiem. Tego rodzaju wystąpienie ma charakter subiektywne- 
go monologu na temat własnych przeżyć wewnętrznych. Innymi słowy powiedzieć można, że jest to liryka w ławach sejmowych. Dlaczego mowa o liryce? Odpowiedź jest tyleż prosta, co oczywista. Liryka (jeden z trzech rodzajów literackich, obok dramatu i epiki) bowiem - zgodnie z definicją - odznacza się wysokim zmetaforyzowaniem i organizacją naddaną tekstu (Gazda, Tynecka-Makowska 2012: 383-384).

Przeżycia wewnętrzne i stan umysłu stanowią elementy tajemnicze i swoiste dla każdej jednostki. Ich zrozumienie to niewątpliwie jeden z warunków sine qua non lepszego poznania i zrozumienia przez innych. Człowiek musi się opierać jedynie na tym, co usłyszy bądź zobaczy. Stąd też zabiegi powodujące ubarwianie przeżyć wewnętrznych, ich zmetaforyzowanie, a niekiedy nawet konfabulacja, cieszą się coraz większą popularnością. Przyczyna tego stanu rzeczy jest prosta - nie zawsze bowiem istnieje możliwość sprawdzenia stopnia prawdomówności interlokutora. Kłamstwo zaś może być w polityce (i nie tylko) gwarantem sukcesu, choć dodajmy - sukcesu krótkotrwałego.

Sięgając do Arystotelesa i stworzonej przez niego klasycznej definicji polityka (Piotrowicz, Szymański 2006), stwierdzić należy, że jest to człowiek działający w sferze polityki, którego element pracy stanowi zdobyta władza i sprawowanie rządów. Przy czym władza ta ma być sprawowana wyłącznie dla dobra wspólnego. Nadto polityk winien być człowiekiem cieszącym się szacunkiem i uznaniem w oczach obywateli (swoich wyborców). Ważne, aby posiadał duży kapitał intelektualny, był obyty i miał ustaloną pozycję w kręgach politycznych i towarzyskich. W dzisiejszych czasach, kiedy dostęp do książek jest niemal nieograniczony, formalna cenzura nie istnieje, a sięganie $\mathrm{w}$ wystąpieniach publicznych do fraz/cytatów

1 Organizacja naddana tekstu - cechy właściwe wyłącznie dla literatury (rytm, melodyka, rymy, powtórzenia, paralele), które są zbędne w przypadku zwyczajnej komunikacji językowej. 
z dzieł literackich powinno świadczyć (choć niekoniecznie świadczy) o oczytaniu i doskonałej pamięci. Poniżej zaprezentowanych zostanie kilka przykładów tego typu zabiegów retorycznych.

\section{Literatura w polityce}

Cieszący się dużą popularnością w Internecie krótki film przedstawiający werbalne starcie polityków w polskim Sejmie jest zatytułowany Nie powiem nawet pies Cie... (http://www.youtube.com/ watch?v=C5yFa1saJjE [dostęp 27.05.2014]). Jego głównymi bohaterami są posłowie Leszek Miller oraz Janusz Palikot. Pierwszy z nich to wielokrotny laureat takich nagród, jak: Order Uśmiechu (odznaczenie o charakterze międzynarodowym przyznawane za działalność na rzecz dzieci), Wiktor (nagroda Akademii Telewizyjnej wręczana osobowościom „małego ekranu”) czy Srebrne Usta (przyznawane przez Program III Polskiego Radia za najbardziej oryginalne, nieszablonowe, zabawne i zaskakujące wypowiedzi). Dzięki własnemu samozaparciu osiągnął szczyty politycznej kariery - od roku 1993 (z małymi przerwami) przewodniczący Sojuszu Lewicy Demokratycznej, były premier i były minister spraw wewnętrznych. Jak opisuje siebie na swoim blogu i stronie internetowej (http://leszek-miller.blog.onet.pl/ [dostęp 27.05 2014]), jest człowiekiem dbającym o dobro kraju, z którego pochodzi. Janusz Palikot natomiast to osoba będąca w polityce o wiele krócej niż Leszek Miller. Założyciel i przewodniczący Ruchu Palikota (obecnie: Twojego Ruchu, rok 2014), jest również przedsiębiorcą i pracownikiem naukowym. Głosi lewicowe poglądy, w które wplata akcenty prawicowe (niekiedy skrajne, wystarczy wspomnieć choćby wydawane przez niego czasopismo „Ozon”). Palikot jest honorowym obywatelem swojego macierzystego miasta - Biłgoraja.

Podczas debaty na temat systemu emerytalnego, odbywającej się 8 grudnia 2013 r. (chodziło o podniesienie wieku, w którym będzie 
można przejść na zasłużony zawodowy odpoczynek), doszło do ostrej wymiany zdań między Leszkiem Millerem a Januszem Palikotem. Ich wystąpienia miały charakter emocjonalny i były raczej dalekie od zasad etyki poselskiej. Pomimo iż nie padały wulgaryzmy, śmiało stwierdzić można, że zarówno forma, jaki i treść wypowiedzi obu panów stanowiły klasyczny przykład zaprzeczający ideałowi polityka (oczywiście w ujęciu Arystotelesa). Podczas sprzeczki Janusz Palikot zarzucił Leszkowi Millerowi niestosowanie się do siódmego przykazania Bożego, tj. „Nie kradnij”, a także przepowiedział mu rychły koniec kariery politycznej. Wspomniał również o szalejącej wśród polityków obłudzie. Jednak to Leszek Miller stał się głównym obiektem ataków Palikota. Obaj interlokutorzy usadowieni byli w ławach sejmowych obok siebie (w jednym rzędzie, w jednej ławie, oddzieleni jedynie siedzącą między nimi posłanką Anną Grodzką). Leszek Miller wykazał się dużą erudycją i spokojem, choć dało się wychwycić na filmie ślady napięcia (pocieranie rąk, zmarszczenie czoła, nerwowy uśmiech). Na zarzuty szefa Twojego Ruchu odpowiadał ze stoickim spokojem, zaś słowa dotyczące jego przyszłości wręcz go bawiły. Chwilami jednak, najprawdopodobniej starając się wyprowadzić Janusza Palikota z równowagi, zachowywał się arogancko - na przykład czytał gazetę. Swoim zachowaniem bawił posłów, w myśl Goffmanowskiej teorii dramaturgicznej, która zakłada, że obecność innych ludzi przeobraża zachowanie człowieka w przedstawienie mające na celu przede wszystkim wywarcie wrażenia (Goffman 2008). Leszek Miller odparł zarzuty stawiane mu przez Janusza Palikota, posługując się cytatem z wiersza Juliana Tuwima Na pewnego endeka, co na mnie szczeka:

Próżnoś repliki się spodziewat, Nie dam Ci prztyczka ani klapsa,

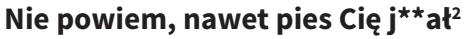

bo to mezalians bytby dla psa.

2 Wyróżnienie własne - I. W.-S. 
Przewodniczący SLD, wykorzystując twórczość Tuwima, chciał w sposób grzeczny, acz dosadny upokorzyć Janusza Palikota i ostudzić jego oskarżycielskie zapędy pod swoim adresem. Komizm całej sytuacji polega na tym, że przedstawienie to najbardziej ubawiło poselską publiczność i to w zasadzie ona decydowała o tonie wypowiedzi i temperaturze sporu.

Cytowanie utworów literackich pozwala na trafne przekazanie własnych uczuć, emocji i przekonań bez narażania się na oskarżenia o obrazę kogoś lub czyichś uczuć. Dlatego też przewodniczący Sojuszu Lewicy Demokratycznej niemal po mistrzowsku wybrnął z sytuacji, w której znalazł się tego dnia.

Kolejnym przykładem wykorzystywania twórczości literackiej przez polityków jest fragment wystąpienia prezesa partii Prawo i Sprawiedliwość - Jarosława Kaczyńskiego. Sięgnął on po cytat z wiersza Przesłanie Pana Cogito Zbigniewa Herberta (Herbert 2008). Utwór ten stanowił swego rodzaju manifest opozycji antykomunistycznej w czasach PRL. Oburzenia, jakie wywołało zachowanie Jarosława Kaczyńskiego (m. in. wdowa po poecie Katarzyna Herbert zaprotestowała przeciwko wykorzystywaniu twórczości jej męża do doraźnych celów politycznych), nie spodziewał się nawet sam prezes PiS.

Cytat, po który sięgnął Jarosław Kaczyński, miał być oskarżeniem skierowanym przeciwko polityce prowadzonej przez jego największego politycznego konkurenta, a można powiedzieć nawet wroga - Donalda Tuska. Lider Platformy Obywatelskiej miał zostać pokazany jako przywódca marionetkowy, sterowany z zewnątrz, czyli przez Rosję. Fragment Przesłania Pana Cogito, w którym jest mowa o „zdradzonych o świcie”, jest niezwykle sugestywny i mocny w swojej wymowie. Zaś użyty w odpowiednim kontekście (rocznica katastrofy smoleńskiej) brzmi wręcz oskarżycielsko:

niech nie opuszcza ciebie twoja siostra Pogarda

dla szpiclów katów tchórzy - oni wygrają 
pójdą na twój pogrzeb i z ulgą rzucą grudę a kornik napisze twój uładzony życiorys i nie przebaczaj zaiste nie w twojej mocy przebaczać w imieniu tych których zdradzono o świcie ${ }^{3}$ strzeż się jednak dumy niepotrzebnej oglądaj w lustrze swą błazeńską twarz powtarzaj: zostałem powołany - czyż nie było lepszych

Zdaniem Kaczyńskiego, Herbert swoją poezją przyczynił się do „odbudowy naszego poczucia siły i naszego poczucia związku z wartościami”. Pokazywał, że to etyka i estetyka nakazują „sprzeciwianie się złu”. Prezes Kaczyński dawał również do zrozumienia, że między tamtą Polską a dzisiejszą nie ma różnicy jakościowej, zrównując tym samym Polskę niepodległą z Polską komunistyczną. Interesujący tutaj jest fakt, że cytat ów jest wyrwany z kontekstu, a na powrót w nim osadzony zupełnie zmienia swoje znaczenie.

Niedomówienia związane z rzeczonym wystąpieniem Jarosława Kaczyńskiego jeszcze bardziej pogłębiły i tak już niezwykle ostry konflikt między dwiema partiami.

Innym przykładem wykorzystania autorytetu literackiego i moralnego zarazem jest sięgnięcie do poezji księdza Jana Twardowskiego. Lech Kaczyński, jak przystało na człowieka wykształconego i humanistę, znał twórczość Twardowskiego, dlatego wykorzystał fragment jego wiersza w jednym ze swoich wystąpień. Niestety, omyłkowo autorstwo zwrotu: „Spieszmy się kochać ludzi tak szybko odchodzą” przypisał Zbigniewowi Herbertowi. Sytuacja ta miała miejsce w Brukseli w czerwcu 2009 r. podczas konferencji prasowej. Prezydent Kaczyński sięgnął po słowa księdza Twardowskiego ze względu na autorytet, jakim cieszy się on w kraju i za granicą (Twardowski 2009: 119). Odwoływanie się do tej miary postaci, jak też cytowanie ich myśli, utworów czy wypowiedzi, wydaje się być znakomitym zabiegiem retorycznym.

3 Wyróżnienie własne - I. W.-S. 
Następny w kolejności przykład odwołania się do literatury stanowi wypowiedź senatora Platformy Obywatelskiej Mariusza Witczaka, który podczas jednej z konferencji prasowych wykorzystał zabieg retoryczny, jakim jest parafraza ${ }^{4}$ (Sławiński 2008: 371). Odpowiadając na słowa przedmówczyni Beaty Szydło (PiS), przywołał fragment poematu Czesława Miłosza Piosenka o końcu świata (Miłosz 2011: 206). Przedstawicielka Prawa i Sprawiedliwości porównując fragmenty pierwszego expose premiera Donalda Tuska z konkretnymi działaniami rządu, chciała ośmieszyć i postawić w niekorzystnym świetle Platformę Obywatelską. Zestawienie szumnych planów i zapowiedzi z wynikami ich realizacji stanowiło dla pani poseł Szydło centralny punkt nie tylko jej wypowiedzi, ale też całej konferencji. Kwitując to cytatem z wiersza Cypriana Kamila Norwida:

Klaskaniem mając obrzękłe prawice, Znudzony pieśnią lud wołał o czyny

posłanka PiS w ten sposób oceniała politykę największego wroga własnej partii. Wykorzystany przez panią Szydło cytat, skomplikowany w swojej treści i wymowie (twórczość Norwida wymaga od odbiorcy dużego oczytania, rozeznania w kulturze i wysiłku intelektualnego), dla osób niebędących znawcami literatury, mógł okazać się zbyt trudny do zrozumienia. Celem przywołania fragmentu wiersza autorstwa „piątego wieszcza” (jak w kręgach znawców literatury nazywany jest Norwid) było uświadomienie nakazu podjęcia efektywnych działań mających na celu zrealizowanie przez premiera i rząd zapowiedzi oraz obietnic złożonych przez Donalda Tuska w trakcie wygłaszania pierwszego expose.

4 Parafraza (gr. paraphrasis - omówienie) - przeróbka utworu literackiego, rozwijająca, często także swobodnie i żartobliwie upraszczająca jego treści, oddająca je za pomocą środków odmiennych niż zastosowane w pierwowzorze, przy zachowaniu jednak rozpoznawalnego podobieństwa do owego pierwowzoru. 
By pełniej przedstawić zagadnienie cytowania, wyjdziemy na moment poza sale parlamentarne.

Nie pozostając $\mathrm{w}$ tyle za innymi politykami, Janusz Korwin-Mikke (szef partii Kongres Nowej Prawicy) podczas programu telewizyjnego Tak czy Nie, w rozważaniach na temat tego, czy politycy powinni zastąpić sądy w wyjaśnianiu afer, skomentował debatę słowami Henryka Sienkiewicza:

Lewicę i prawicę dzieli wszystko również stosunek do znaków arytmetycznych.

Prawica lubi dodawać i mnożyć, a lewica lubi odejmować i dzielić, po równo oczywiście.

Janusz Korwin-Mikke (w polityce od 1962 r., absolwent Uniwersytetu Warszawskiego, od 2014 r. członek Parlamentu Europejskiego) to niewątpliwie polityk charyzmatyczny i niezwykle medialny, nie tylko za sprawą nietuzinkowych i odbiegających od kanonu zachowań, ale także rozpoznawalny dzięki muszce stanowiącej nieodłączną część jego stroju. Korwin-Mikke jest politykiem kontrowersyjnym, głoszącym nie mniej kontrowersyjne poglądy, który cieszy się nieustającą popularnością. Odwołując się do Henryka Sienkiewicza, chciał w sposób dosadny, obrazowy i bezpośredni zaprezentować swój pogląd na temat roli polityków w wyjaśnianiu afer. Zilustrowane cytatem z Sienkiewicza różnice między prawą a lewą stroną sceny politycznej są skrajne i wydają się niemożliwe do pogodzenia. Samo zaś przytoczenie słów polskiego noblisty stanowiło odpowiedź na pytanie o to, czy sądy powinny być zastąpione politykami.

Korwin-Mikke w swoich wystąpieniach wykorzystuje również fragmenty z Biblii. W wywiadzie dla jednego z portali internetowych na temat projektu dotyczącego darmowych leków dla osób będących na emeryturze popierał wypowiedź Jana Filipa Libic- 
kiego ${ }^{5}$, który stanowczo odrzucał tenże pomysł (http://www.senat.gov.pl/sklad/senatorowie/senator,98,8,jan-filip-libicki.html [dostęp 25.09.2015]). Swoją aprobatę dla członka Platformy Obywatelskiej wyrażał poprzez propozycję wstąpienia do Kongresu Nowej Prawicy. Zaproszenie to, choć wypowiedziane $\mathrm{w}$ formie żartu, skwitowane zostało cytatem z Ewangelii Świętego Łukasza pt. Bóg jest miłosierny dla grzeszników (Pismo Święte Starego i Nowego Testamentu 2015: 1499):

Większa radość z jednego nawróconego grzesznika niż z dziewięćdziesięciu dziewięciu sprawiedliwych.

Powołanie się na Biblię zazwyczaj ma wymiar symboliczny i najprawdopodobniej o to właśnie chodziło Januszowi Korwinowi-Mikke. Zmiana rodzimej partii na inną, konkurencyjną przez Jana Libickiego oznaczałaby w mniemaniu przywódcy Kongresu Nowej Prawicy wręcz nawrócenie.

W niniejszym opracowaniu należałoby również wspomnieć o Grzegorzu Schetynie, polityku Platformy Obywatelskiej, który na swojej stronie internetowej przedstawia się jako absolwent historii Wydziału Filozoficzno-Historycznego Uniwersytetu Wrocławskiego i miłośnik koszykówki (http://www.schetyna.pl/omnie [dostęp 27.12.2014]). Grzegorz Schetyna już od młodych lat interesował się polityką (odnotowana jest jego obecność w Niezależnym Zrzeszeniu Studentów, Solidarności Walczącej). Potem stopniowo piął się po szczeblach kariery politycznej. Podczas rozmowy w dniu 28 października 2013 r. z dziennikarzem stacji telewizyjnej TVN na temat swojej porażki w wewnętrznych wyborach Platformy na liderów poszczególnych regionów (http://www. tvn24.pl/wideo/z-anteny/schetyna-cytuje-wierszmilosza,955677.

5 Jan Libicki - osoba ściśle związana z Poznaniem, tam zdobył wykształcenie oraz rozpoczynał karierę polityczną, od roku 2011 senator RP VIII kadencji. 
html?playlist_id=18835 [dostęp 27.12.2014]), w odpowiedzi na pytanie przedmówcy o to, czy i jakie posiada on wsparcie ze strony premiera (przewodniczącego swojej partii), zacytował słowa (które można by zrozumieć jako aluzję) autorstwa Czesława Miłosza z wiersza pt. Który skrzywdziłeś (Miłosz 2011: 341):

Nie bądź bezpieczny. Poeta pamięta.

Możesz go zabić - narodzi się nowy.

Spisane będą czyny i rozmowy. ${ }^{6}$

Po tych słowach, nie dyskutując i nie podważając możliwości wypowiedzenia tych słów przez Donalda Tuska, usiłował skierować rozmowę na inny tor. Poprzez użycie tego sformułowania Grzegorz Schetyna wydaje się, że próbował wybrnąć z pytania, które było dla niego niekomfortowe - czego oznaką może być nerwowy uśmiech na twarzy.

Ostatnim podawanym tutaj przykładem powoływania się przez polityka na czyjąś twórczość jest wypowiedź Jacka Majchrowskiego $^{7}$ (https://www.bip.krakow.pl/?id=96 [dostęp15.08 2014]). W programie telewizyjnym TVP Kraków pt. Polityka bli$\dot{z}$ ej pytanie dziennikarza o to, czy jest w koalicji z radnymi z partii PO, skwitował on słowami Jana z Czarnolasu (Kochanowski 1976: 63):

Wielkieś mi uczyniła pustki w domu moim, Moja droga Orszulo, tym zniknieniem swoim!

Pełno nas, a jakoby nikogo nie było

(tu zastąpione przez: Jest a jakby jej nie było)

Jedną maluczką duszą tak wiele ubyło.

Tyś za wszytki mówiła, za wszytki śpiewała,

6 Wyróżnienie własne - I. W.-S.

7 Jest to polityk bezpartyjny, od 2002 r. nieprzerwanie prezydent miasta Krakowa. Zawodowo związany również z Uniwersytetem Jagiellońskim, profesor zwyczajny nauk prawnych, historyk doktryn politycznych i prawnych. 
Wszytkieś w domu kąciki zawżdy pobiegała. Nie dopuściłaś nigdy matce się frasować Ani ojcu myśleniem zbytnim głowy psować, To tego, to owego wdzięcznie obłapiając I onym swym uciesznym śmiechem zabawiając. Teraz wszytko umilkło, szczere pustki w domu, Nie masz zabawki, nie masz rozśmiać się nikomu. Z każdego kąta żałość człowieka ujmuje, A serce swej pociechy darmo upatruje.

Cytat użyty nie dosłownie, ale prezentujący w dwuznaczny, lub nawet wieloznaczny, sposób pogląd mówcy na poruszony temat. Cytat dopuszcza w danym kontekście wiele interpretacji i jest odpowiedzią-unikiem na pytanie dziennikarza. Cytaty z literatury pięknej mają zatem także funkcję zaciemniania odpowiedzi i czynienia jej wieloznaczną.

\section{Zakończenie}

W polityce literatura piękna w cytowaniach (chociaż nie pojawia się zbyt często) wyraża to, czego prawdopodobnie wprost powiedzieć nie wypada. Cytowanie chroni przed oskarżeniami i atakami, tak ze strony przeciwników politycznych, jak i mediów. Przytoczenia literackie pozwalają na przekazanie własnych odczuć ukrytych lub jawnych, albo niecenzuralnych myśli (Konecki 2014). Znane passusy w publicznych wystąpieniach polityków wzbudzają szerokie zainteresowanie za sprawą niedomówień, które mogą z nich wynikać.

Liczba wyświetleń, odsłon w telewizji, postów na portalach internetowych świadczy o szerokim zainteresowaniu tego rodzaju chwytami retorycznymi stosowanymi przez polityków. Popularność zdobywana przez polityków, którzy wielokrotnie stają się sprawcami zamieszania medialnego, stanowi dodatkowy argument przesądzający o tym, że chętnie sięgają oni po cytaty lite- 
rackie. Jest to bowiem zarówno reklama personalna dla samego polityka, jak i partii lub poglądów, które reprezentuje.

Pozytywem wykorzystywania twórczości literackiej przez polityków oraz osoby znane szerszej publiczności jest to, że odbiorcy bardzo często decydują się sięgnąć do źródła cytatu. Dzieje się tak dlatego, że chcą zweryfikować wierność cytatu oraz jego autorstwo, zaś w przypadku błędu dokonać sprostowania i korekty.

Cytowanie to znakomity chwyt marketingowy, który zwiększa moc perswazyjną wypowiedzi. Jest jednak kilka warunków jego powodzenia. Po pierwsze, zacytowanie słów musi być wierne i wolne od błędów. Po drugie, należy użyć cytatu w odpowiednim kontekście sytuacyjnym.

Osoby, o których była do tej pory mowa (Leszek Miller, Jarosław Kaczyński, Lech Kaczyński, Mariusz Witczak, Beata Szydło, Janusz Korwin-Mikke, Grzegorz Schetyna i Jacek Majchrowski), parafrazowały bądź dosłownie przytaczały pewne cytaty. Tego rodzaju zabiegi retoryczne, jak w wypowiedziach wyżej wymienionych polityków, sprawiają, że stają się one medialne i można pokusić się o stwierdzenie, że zwiększają oglądalność serwisów informacyjnych.

Sięganie przez polityków po cytaty, passusy i parafrazy niewątpliwie przyczynia się do tworzenia się w świadomości odbiorców - pożądanego przez przedstawicieli władzy wykonawczej lub ustawodawczej - ich wizerunku medialnego i wyróżnienia się spośród politycznych konkurentów. Odwoływanie się do dzieł literackich wpływa również na umocnienie pozytywnego wizerunku polityka, głównie poprzez budowanie wrażenia osoby wykształconej i obytej w świecie kultury.

Demonstrowanie kompetencji kulturowych ${ }^{8}$ podczas wystąpień publicznych stanowi dowód zaangażowania polityków

8 Kompetencje wyróżnione przez organy instytucjonalne Unii Europejskiej zajmujące się edukacją, będące jednym z elementów składających się na szereg kompetencji nauczyciela oraz obywateli Wspólnoty. 
w problemy natury ogólnej, a co za tym idzie - zainteresowania, które może przerodzić się w działanie. Oddziaływanie na odbiorców w sposób werbalny wzmocniony o cytat (a więc o autorytet osoby cytowanej) jest jednym z wielu sposobów zwrócenia uwagi na siebie.

\section{HIGHBROW CULTURE IN POLITICS}

Abstract. Quoting other people's arguments by politicians, to rely on someone else's work is rarely seen, but often causing extreme emotions. Recalling (especially inaccurate) the fragment from foreign language authors can cause misunderstanding, confusion of content and change the original meaning. The rhetorical device of this kind can be traced and watched several times by access to the media, what was done in our sociological analysis. Politicians, like actors, through the selection of specific measures of self-presentation (in this case, quotations from literature, cite the author of the widely known) provide customers reality as amended, such that they would like to be seen (Goffman 2008). The analyzed verbal speech in the Sejm were characterized by a strong emotional tone and illustrates language, that is far from the classical canons of savoir vivre (Marcjanik 2014; Achtelik, Tambor 2013). Verbal bon ton in parliament has, through its application, fulfilled many functions, from polite sarcasm through the manifesto of the supremacy, to the personal presentation of erudition. At the outset, the author describes leading concepts used in the chapter. In the next part the author addresses the videos with the participation of politicians who during their public appearances quoted of another authors. In summary the author of the chapter focuses on the function of citations and there are taken into account the positive aspects of using the prose/poetry by individuals elected to public office.

Key words: politics, politicians, literature, emotions, highbrow culture 


\section{Bibliografia}

Arystoteles (2006), Polityka, przeł. Ludwik Piotrowicz, Mikołaj Szymański, PWN, Warszawa

Achtelik, Aleksandra, Jolanta Tambor (red.) (2013), Sztuka czy rzemiosto? Nauczyć Polski i polskiego, t. 3, Gnome, Katowice

Pismo Święte Starego i Nowego Testamentu (2015), Nowy Testament, Łk 15, 7-8, Święty Wojciech, Poznań

Gazda, Grzegorz, Słowinia Tynecka-Makowska (red.) (2006), Stownik rodzajów i gatunków literackich, Universitas, Kraków

Goffman, Erving (2008), Człowiek w teatrze życia codziennego, Wydawnictwo Aletheia, Warszawa

Herbert, Zbigniew (2008), Pan Cogito, Wydawnictwo A5, Warszawa

Kochanowski, Jan (1976), Dzieła polskie,

t. 2, Państwowy Instytut Wydawniczy, Warszawa

Korolko, Mirosław (1998), Sztuka retoryki. Przewodnik encyklopedyczny, wyd. 2 rozszerzone, Wiedza Powszechna, Warszawa

\section{Netografia}

http://www.wybory.com.pl/link/slow$\mathrm{nik} / 15 /$ [dostęp 24.05.2014]

http://www.miller.pl/ [dostęp 27.05.2014] http://leszek-miller.blog.onet.pl/ [dostęp 27.05.2014]

https://www.bip.krakow.pl/?id=96/ [dostęp 15.08.2014]

http://krakow.tvp.pl/15851891/prof-jacek-majchrowski-prezydent-krakowa/ [dostęp 15.08.2014]
Konecki, Krzystof, Kathy Charmaz, Barbara Komorowska (2009), Teoria ugruntowana: praktyczny przewodnik po analizie jakościowej, PWN, Warszawa

Konecki, Krzysztof, Beata Pawłowska (red.) (2014), Emocje w życiu codziennym. Analiza kulturowych, społecznych i organizacyjnych uwarunkowań ujawniania i kierowania emocjami, Wydawnictwo Uniwersytetu Łódzkiego, Łódź

Marcjanik, Małgorzata (2014), Stownik językowego savoir vivre'u, Wydawnictwa Uniwersytetu Warszawskiego, Warszawa

Miłosz, Czesław (2011), Wiersze wszystkie, Znak, Kraków

Norwid, Cyprian Kamil (1969), Vade-mecum, Państwowy Instytut Wydawniczy, Warszawa

Sławiński, Janusz (red.) (2008), Słownik terminów literackich, wyd. 5, Ossolineum, Wroctaw

Twardowski, Jan (2009), Tylko miłość się liczy, Święty Wojciech, Poznań

http://www.sejm.gov.pl/sejm7.nsf/posel.xsp?id=285 [dostęp 27.05.2014] http://januszpalikot.natemat.pl/ [dostęp 27.05.2014]

http://www.tvn24.pl/wideo/z-anteny/ schetyna-cytuje-wierszmilosza,955677. html?playlist_id=18835 [dostęp 27.12.2014]

http://www.schetyna.pl/o-mnie [dostęp 27.12.2014] 


\section{Kultura wysoka w polityce}

http://www.senat.gov.pl/sklad/senatorowie/senator,98,8,jan-filip-libicki. html [dostęp 25.09.2015]

http://www.youtube.com/watch?v=C5yFa1saJjE [dostęp 27.05.2014]

http://www.wiadomosci24.pl/artykul/ przeslanie_pana_cogito_230418. html [dostęp 28.04.2014]

http://www.tvp.info/16402410/jan-filip-libicki-to-ja-zabralem-darmowe-leki-emerytom [dostęp 28.12.2014] http://wiadomosci.onet.pl/1995483,11, item.html [dostęp 28.05.2014] http://www.polskieradio.pl/5/3/Arty$\mathrm{kul} / 272727$,PiS-mowi-Norwidem-PO -odpowiada-Miloszem [dostęp 28.05 .2014]

http://www.youtube.com/watch? $\mathrm{v}=$ liqiqwSGEIU [dostęp 27.05.2014] 